\title{
DETERMINANTS OF GROSS REGIONAL DOMESTIC PRODUCT IN EASTERN INDONESIA REGION 2011-2016
}

\author{
Istiqomah \\ istiqomahsubechan@gmail.com \\ Arif Andri Wibowo \\ Evi Yunianti \\ Diah Setyorini Gunawan \\ Fakultas Ekonomi dan Bisnis, Universitas Jenderal Soedirman \\ Jl. Prof. Dr. HR Boenyamin 708, Purwokerto 53122
}

received: 19/11/18; revised: 7/12/18; published: 29/6/19

\begin{abstract}
Regional income equality has been a major development goal. However, GRDP in Western Indonesia is higher than that in Eastern Indonesia. Therefore, the government should encourage development and increase economic growth in Eastern Indonesia. There are inequalities between those provinces. The purpose of this research is to analyze the effect of labor, domestic investment, foreign direct investment, and government expenditure on GRDP in Eastern Indonesia Region. This study employed regression on panel data of 12 provinces from 2011 to 2016. The results found that labor, domestic investment, foreign direct investment, and government expenditure have positive and significant effect to GRDP. The results imply that all of the independent variables shuld be increas to promote economic growth in The Eastern Indonesia Region.
\end{abstract}

Keywords: regional income disparity; GRDP; labor; domestic investment; foreign direct investment; government expenditure; eastern indonesia region

\section{INTRODUCTION}

There are several indicators to measure the success of development, one of which is economic growth. Economic growth is a concept of an increase in output per capita in the long term, both at national and at lower levels at the provinces and districts/municipalities. Economic growth indicates the extent to which economic activity will generate additional income for a given period of time. In other words, the economy is said to have grown when the real income of society in a given year is greater than the actual income of the community in the previous year.

The main purpose of economic development besides creating the highest economic growth should also reduce poverty, income inequality and unemployment (Todaro $\&$ Smith, 2011). Employment opportunities will provide income to meet the needs. Therefore, the results of development should be enjoyed by all people in a fair and equitable way. However, sometimes the results of development are not evenly distributed between regions.

Development regions in Indonesia are divided into two areas, namely the western region and eastern region. The Western region includes Sumatera, Java, Kalimantan, and Bali, while the Eastern region includes
Sulawesi, Maluku, Papua, and Nusa Tenggara. Indonesian development has been dominated by provinces that belong to the Western region of Indonesia, which makes development in Eastern Indonesia left behind (BPS, 2016). BPS shows that 80 percent of Indonesia's Gross Domestic Product (GDP) is dominated by provinces in Western Indonesia, while the remainder is distributed throughout provinces in Eastern Indonesia. In fact, the fundamental issue is not only to grow GRDP, but rather to who will grow the GRDP. If only a few wealthy people who grow GRDP, then the benefits of growth are only enjoyed by them alone so that poverty and income inequality will get worse. GRDP in Western Indonesia region and Eastern Indonesia region can be seen at Figure 1.

Figure 1 indicates that the GRDP in Western Indonesia is higher and grows faster than that in Eastern Indonesia. One of the government policies to reduce the level of development gap between regions is the implementation of development policies through the concept of potential regions (kawasan andalan). Through this policy, it is expected that there will be a balance in economic growth between regions in order to close the gap between the economic development of Java and other islands. Figure 1 also shows that in 
the last six years the GRDP of provinces in Eastern Indonesia increases every year. However, there has been inequality between those provinces. The lowest GRDP is observed in the province of North Maluku and the highest GRDP is in the province of South Sulawesi.

According to traditional neoclassical growth theory, growth of output results from the increase in one or more of these factors: labor quantity and quality (through population growth and education), capital (through saving and investment), and improved technology (Sukirno, 2010, p. 44; Todaro \& Smith, 2011, p. 30). According to Keynesian perspective, government spending stimulates aggregate demand. Conversely, the neoclassical approach assumes that government spending does not influence economic growth (Kaminsky, 2009). This research aims to test whether labor quantity, domestic investment, foreign direct investment, and government expenditure explain the variation of output in the Eastern Indonesian region.

\section{METHODS}

This research is a quantitative research, defined as a type of research that produces findings that can be achieved by using statistical procedures or other means of quantification/measurement (Sujarweni, 2014). Using secondary data from The Central Bureau of Statistics (BPS), this research covers 12 provinces in Eastern Indonesia over the period of 2011-2016. The Provinces in Eastern Inodonesia includes North Sulawesi, South Sulawesi, Central Sulawesi, Southeast Sulawesi, Gorontalo, West Sulawesi, Maluku, North Maluku, Papua, West Papua, East Nusa Tenggara, and West Nusa Tenggara. The dependent variable is GRDP and the independent variables are labor, domestic investment, foreign direct investment, and government expenditure. This research analyzes the effect of labor, domestic investment, foreign direct investment and government expenditure on GRDP of Eastern Indonesia region using time series data for six years represented by annual data from 2011-2016. Data were then analyzed by panel data regression. The panel data regression can be calculated with the following formula (Gujarati \& D C Porter, 2012):

$$
\log Y_{i t}=\beta_{0}+\beta_{1} X_{1 i t}+\beta_{2} d X_{2 i t}+\beta_{3} X_{3 i t}+B_{4} \log X_{4 i t}+\varepsilon_{i t}
$$

Where $\mathrm{Y}$ is GRDP, $\mathrm{X} 1$ is labor, $\mathrm{X} 2$ is domestic investment, $\mathrm{X} 3$ is FDI, $\mathrm{X} 4$ is government expenditure, $\mathrm{i}$ is cross section, $\mathrm{t}$ is time series, $\beta 0$ is constant, $\mathrm{B} 1-4$ is coefficient, and $\varepsilon$ is eror term. To find out which model is the best whether to use Common Effect (Cem), Fixed Effect (FEM), or Random Effect (REM), chi square analysis is performed. In this research, REM cannot be applied because the number of $i$ is less than the number of $\mathrm{t}$ (Nachrowi \& Usman, 2006).

\section{RESULTS}

Figure 2 shows that in general GRDP in Eastern Indonesia during 2011-2016 has increased every year. The highest GRDP was observed in South Sulawesi. South Sulawesi plays an important role as the gateway of Eastern Indonesia region. The role of South Sulawesi province is very strategic in supporting Sulawesi Island as a center of production and processing of agricultural, plantation, fishery, and nickel mining, especially as food agriculture node, fishery node, and industrial cluster (BAPPENAS, 2015).

Figure 3 shows that the province of South Sulawesi has the highest number of labor among other provinces. The number of small-scale industries in South Sulawesi Province in 2013 is mostly in the food, beverage and tobacco industries of 174 companies with a total workforce of 4,621 people. The biggest employment of large medium-scale industry group is in wood $(6,665$ persons) and non-metal mining industries $(6,805$ persons), respectively. Industrial sector development in South Sulawesi is increasing every year (BAPPENAS, 2015).

Figure 4 presents the data on domestic investment in Eastern Indonesia Region during 2011-2016. In general, the provinces in Eastern Indonesia have a relatively low domestic investment inspite of larger area and bigger potential of natural resources.

Figure 5 shows that foreign direct investment varies greatly among provinces and has been fluctuating during 2011-2016. Foreign direct investment is expected as one of the financing sources in development that can be used to build infrastructure such as ports, electricity, clean water, roads, railways and others, and to transfer technology.

Figure 6 shows that government expenditure in every province in Eastern Indonesia Region fluctuated during the period of 2011-2016. Southeast Sulawesi is the province with the highest government expenditure.

Chow test is a test for model selection to select between common effect and fixed effect. The value of error probability $(0.0000)$ is smaller than 0.05 , it means $\mathrm{H}_{0}$ is rejected and $\mathrm{H}_{1}$ is accepted, meaning that the model used is fixed effect. Hausman test is used to select between fixed effect and random effect model. The value of error probability $(0.0000)$ is smaller than $5 \%$, it means $\mathrm{H}_{0}$ is rejected and $\mathrm{H}_{1}$ is accepted, the model used is fixed effect. According to Gujarati \& Porter (2012), model selection between fixed effect or random effect model on panel data can be done by observing total number of time series ( $\mathrm{t}$ ) and cross section (n). When $t$ is greater than $n$, fixed effect is used, and when $\mathrm{n}$ is greater than $\mathrm{t}$, the model used is random effect. In this research, $t$ is greater than $n(10>8)$, so fixed effect model should be chosen. The hausman test also suppports the decision. 
The regression analysis of the factors that affect GRDP in Eastern Indonesia Region as seen in Table 1, shows an equation as follows:

$$
\begin{aligned}
\operatorname{LogGRDP}= & 1.549254+0.00000113 \text { Labor }_{\text {it }}+ \\
& 0.00000904 \mathrm{dDi}_{i \mathrm{it}}+0.000033 \mathrm{FDI}_{\mathrm{it}}+ \\
& 0.535283 \operatorname{LogGovex}_{\mathrm{it}}+\mathrm{e}_{\mathrm{it}}
\end{aligned}
$$

Based on the output, the value of adjusted $\mathrm{R}$ square obtained is 0.996387 . The value is close to 1 which indicates that the GRDP in Eastern Indonesia Region can be explained by labor, domestic investment, foreign direct investment and government expenditure by $99.6 \%$. The results of fixed effect model regression obtained prob (F-statistic) of 0.000000 , so it can be concluded that labor, domestic investment, foreign direct investment and government expenditure simultaneously have significant influence on GRDP in Eastern Indonesia Region.

$t$ test aims to determine wheither each independent variable is individually influential to the dependent variable. In this test the significance level used is $\alpha=$ 0.05 . The test results of $t$ test are as follows:

Labor has t statistic of 6.942344 $>t$ table (2.00324), and has p-value of $0.0000<0.05$. Therefore, labor has a positive significant effect on the GRDP in Eastern Indonesia Region.

Domestic Investment (DI) has t statistic of 2.881244 $>t$ table (2.00324), and has p-value of $0.0061<0.05$. Therefore, DI has a positive significant effect on the GRDP in Eastern Indonesia Region.

Foreign Direct Investment (FDI) has t statistic of $3.660697>t$ table (2.00324), and has p-value of 0.0007 $<0.05$. Therefore, FDI has a positive significant effect on the GRDP in Eastern Indonesia Region.

Government expenditure has t statistic of 9.755265 $>$ t table $(2.00324)$, and has p-value of $0.0000<0.05$. Therefore, Govex has a positive significant effect on the GRDP in Eastern Indonesia Region.

\section{DISCUSSION}

The result of this study shows that labor has positive and significant effect on GRDP. It can be concluded that the increasing labor will increase the GRDP. This research supports the previous research by Rahman et al. (2016), Aziz \& Azmi (2017), and Siddique et al. (2017) who found that labor has positive significant effect on GRDP. An important factor that determines the prosperity of a society is the level of income. The income reaches maximum if full employment usage levels can be realized. By increasing the unempoyment rate in an area, it will cause economic and social problems to people who experience it. The absence of income causes the unemployed to reduce the Eastern Indonesia region consumption, which ultimately results them to reduce the income in the Eastern Indonesia region.
The result of this study shows that domestic investment has insignificant effect on GRDP. Infrastructure becomes the key to achieving a higher GRDP. Infrastructure, especially the means of transportation, will both reduce distribution costs and economize the economy. This research is supported by previous research by Asiyan (2013) and Mefi Hukubun et al. (2015) starting that domestic investment has no significant effect on GRDP, as an example of the fact that PT Freeport Indonesia only benefits its investors and the profits from Freeport do not affect the welfare of Indonesia, especially the local people in Papua province.

The realization of investment in Indonesia until now is still stored in Western Indonesia region. While in Eastern Indonesia region, the realization of investment is still very small. There is still a lot of overlapping licensing between the central government and local government to make investors reluctant to invest.

The result of the research shows that foreign direct investment has positive and significant effect to GRDP. It can be concluded that the increase of foreign direct investment will increase the GRDP. This research is supported by previous research of Iqbal et al. (2014), Agrawal (2015), Rahman et al. (2016), Aziz \& Azmi (2017), and Siddique et al. (2017) who found that domestic investment has a positive effect on GRDP. Investment is a major componen in moving the wheels of a country's economy. Theoretically, the increase in investment will encourage trade volume and production volume which in turn will broaden productive employment opportunities and will increase the income per capita, GRDP and also can improve the welfate of the community. In country with an Export Promotion policy, FDI stimulates human resource development through training, education, technology transfer, more employment and other spillover effects on the host country economy (Iqbal et al., 2014). Hence, if economic growth is likely to attract more FDI inflows, then various policies to attract inward FDI could become unnecessary. Therefore, efforts should also be made to encourage the other potential sources of economic development (Agrawal, 2015). FDI is a key driver of economic growth and development and that FDI not only boosts capital formation but also enhances the quality of capital stock (Evans, Frank, $\&$ Rebecca, 2017).

The result also shows that government expenditure has no effect on GRDP. Small government consumption expenditure will harm economic growth, proportional government expenditure will increase economic growth and consumption expenditure wasteful government will hamper economic growth. In general government expenditure has a positive impact on economic growth. The proportion and development of realization of public expenditure which is relatively smaller compared with the realization of regional apparatus expenditure indicates that the budget allocation is mostly used for the 
benefit of consumption (Szarowsk, 2013). This situation causes the realization of large regional expenditure has not pushed the economic growth of the Province in Eastern Indonesia Region significantly. GRDP is an indicator or benchmark of economic growth which means if the economic growth of an area is low then the GRDP of a region is also low. Musaba et al. (2013) showed that there were no significant relationship between government sectoral expenditure variables and economic growth in the short-run. However, the long run results indicated that government expenditure on agriculture and defense have significant positive impacts on economic growth. Government expenditure on education, health, social protection, and transport and communication were significant but negatively related to economic growth. This implies that expenditure on education, health, social protection, and transport and communication were not contributing to economic growth. In other words, government expenditures in these sectors concentrated more on unproductive activities than productive activities. In order to boost economic growth the government should address the factors causing the negative impact on growth. A well-defined expenditure policy should be pursued and efficient management of resources in the development of education, health, social protection, and transport and communication services should be emphasized.

\section{CONCLUSIONS}

Labor and foreign direct investment have a positive and significant effect on GRDP in Eastern Indonesia Region 2011-2016, domestic investment and government expenditure has a positive and insignificant on GRDP in Eastern Indonesia Region 2011-2016, and the most influential variable on GRDP in Eastern Indonesia Region is labor.

Based on the conclusion of this research, local governments are expected to increase labor productivity through increased budget allocation for education to improve the quality of workforce, provide training for the workforce and expand employment opportunities so that output increases and ultimately can boost GRDP. The investment is strongly influenced by the provision of adequate infrastructure and human resources, so the government needs to improve infrastructure while improving the quality of human resources through education and training.

Basically, the foreign investment climate is most vulnerable to economic, social, political, and cultural issues. Therefore, the government should increase the confidence of foreign investors by maintaining good economic, political, social and cultural stability in the country, as well as by increasing the ease of bureaucracy. The government in Eastern Indonesia is expected to allocate proportional spending between consumptive routine expenditure and development expenditure so as to give positive effect to GRDP in the Eastern Indonesia Region.

\section{REFERENCES}

Agrawal, G. 2015. Foreign Direct Investment and Economic Growth in BRICS Economies : A Panel Data Analysis. Journal of Economics, Business and Management, 3(4), 421-424.

Asiyan, S. 2013. Pengaruh Penanaman Modal Dalam Negeri, Penanaman Modal Asing, Dan Ekspor Terhadap Pertumbuhan Ekonomi Jawa Timur. Journal Unesa, 1(1), 1-18.

Aziz, R. N. A. R., \& Azmi, A. 2017. Factor Affecting Gross Domestic Product (GDP) Growth In Malaysia. International Journal of Real Estate Studies, 11(4), 61-67.

Bappenas. 2015. Laporan Pencapaian Tujuan Pembangunan Milenium Di Indonesia 2014. Jakarta.

BPS. 2016. Statistik Indonesia. Jakarta.

Evans, T., Frank, L., \& Rebecca, J. 2017. The Effect of Foreign Direct Investment ( FDI ) on the Ghanaian Economic Growth. Journal of Business and Econimic Development, 2(5), 240-246.

Gujarati, D. N., \& D C Porter. 2012. Dasar-Dasar Ekonometrika. Jakarta: Salemba Empat.

Iqbal, N., Ahmad, N., Haider, Z., \& Anwar, S. 2014. Impact of foreign direct investment ( FDI ) on GDP : A Case study from Pakistan. International Letters of Social and Humanistic Sciences, 16(1), 73-80.

Kaminsky, G. 2009. Terms of Trade Shocks and Fiscal Cycles. In CA Reserve Bank of Australia and the Cente for Applied Macoeconomic Analysis (CAMA). In Inflation In An Era of Relation Price Shocks. Sydney 17-18 August: Australian National University.

Mefi Hukubun, Rotinsulu, D., \& Niode, A. 2015. Pengaruh Investasi Pemerintah Dan Investasi Swasta Terhadap Pertumbuhan Ekonomi Dan Dampaknya Terhadap Tenaga Kerja Propinsi Sulawesi Utara Tahun 2002-2012. Jurnal Berkala Ilmiah Efisiensi, 15(1), 1-17.

Musaba, E. C., Chilonda, P., \& Matchaya, G. 2013. Impact of Government Sectoral Expenditure on Economic Growth in Malawi, 1980-2007. Journal of Economics and Sustainable Development, 4(2), 71-78.

Nachrowi, N. D., \& Usman, H. 2006. Pendekatan Populer dan Praktis Ekonometrika untuk Analisis Ekonomi dan Keuangan. Jakarta: LPFE Universitas Indonesia.

Rahman, A. J., Soelistyo, A., \& Hadi, S. 2016. Pengaruh Investasi, Pengeluaran Pemerintah Dan Tenaga Kerja Terhadap PDRB Kabupaten/Kota Di Propinsi Banten Tahun 2010-2014. Jurnal Ekonomi Pembangunan, 14, 1-10. 
Siddique, H. M. A., Ansar, R., Naeem, M. M., \& Yaqoob, S. 2017. Impact of FDI on Economic Growth : Evidence from Pakistan. Bulletin of Business and Econmics, 6(3), 111-116.

Sujarweni. 2014. SPSS Untuk Penelitian. Yogyakarta: Pustaka Baru Press.

Sukirno, S. 2010. Makro Ekonomi. Jakarta: Raja

\section{Grafindo Persada.}

Szarowsk, I. 2013. Trends Of COFOG Government Expenditure In The EU15. In Economic Policy in the European Union Member Countries (pp. 280-290).

Todaro, M. P., \& Smith, S. C. 2011. Economic Development (11th ed.). Boston: Pearson.

Table 1. Regression results with fixed effect model

\begin{tabular}{lcccc}
\hline Variable & Coefficient & Std. Error & t-Statistic & Prob. \\
\hline LABOR & $1.13 \mathrm{E}-06$ & $1.63 \mathrm{E}-07$ & 6.942344 & 0.0000 \\
DI & $9.04 \mathrm{E}-06$ & $3.14 \mathrm{E}-06$ & 2.881244 & 0.0061 \\
FDI & $3.30 \mathrm{E}-05$ & $9.03 \mathrm{E}-06$ & 3.660697 & 0.0007 \\
Govex & 0.535283 & 0.054871 & 9.755265 & 0.0000 \\
C & 1.549254 & 0.606272 & 2.555378 & 0.0141 \\
\hline \multicolumn{2}{l}{ Source: Data processed, 2018 }
\end{tabular}

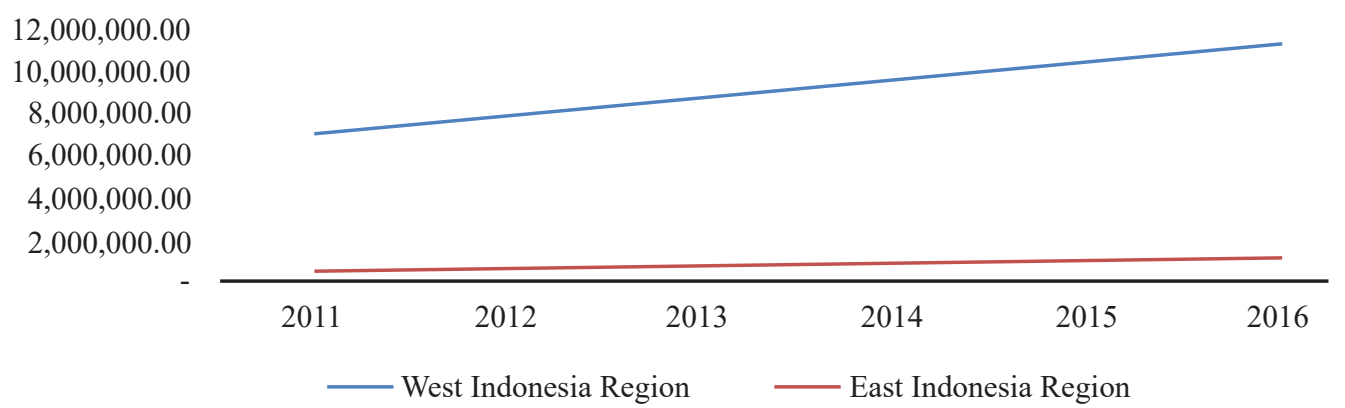

Source: The Central Bureau of Statistics, 2018

Figure 1. GRDP at current prices by province (Billion Rupiah) in Western and East Indonesia region 2011-2016

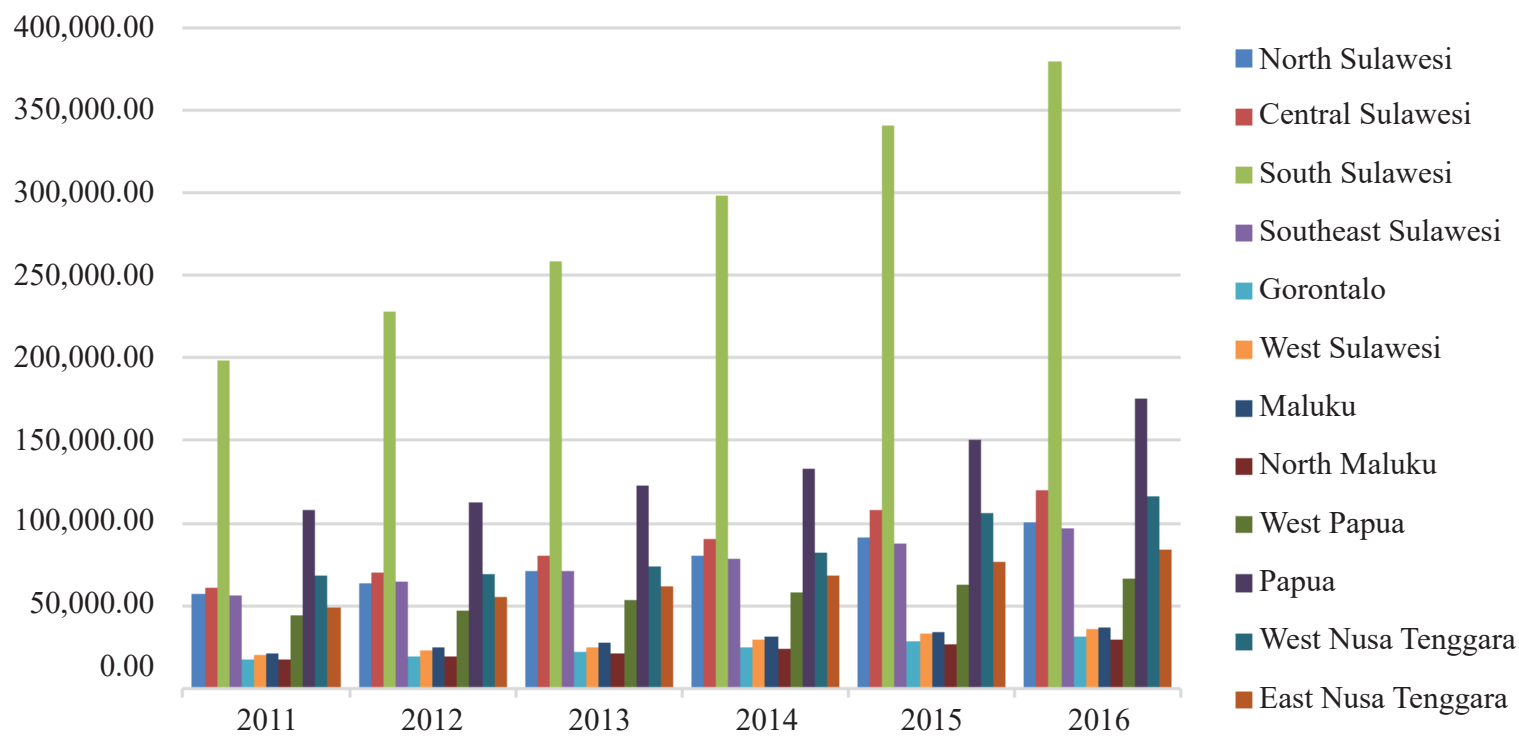

Source: The Central Bureau of Statistics, 2018

Figure 2. GRDP in Eastern Indonesia Region 2011-2016

(Billion Rupiah) 


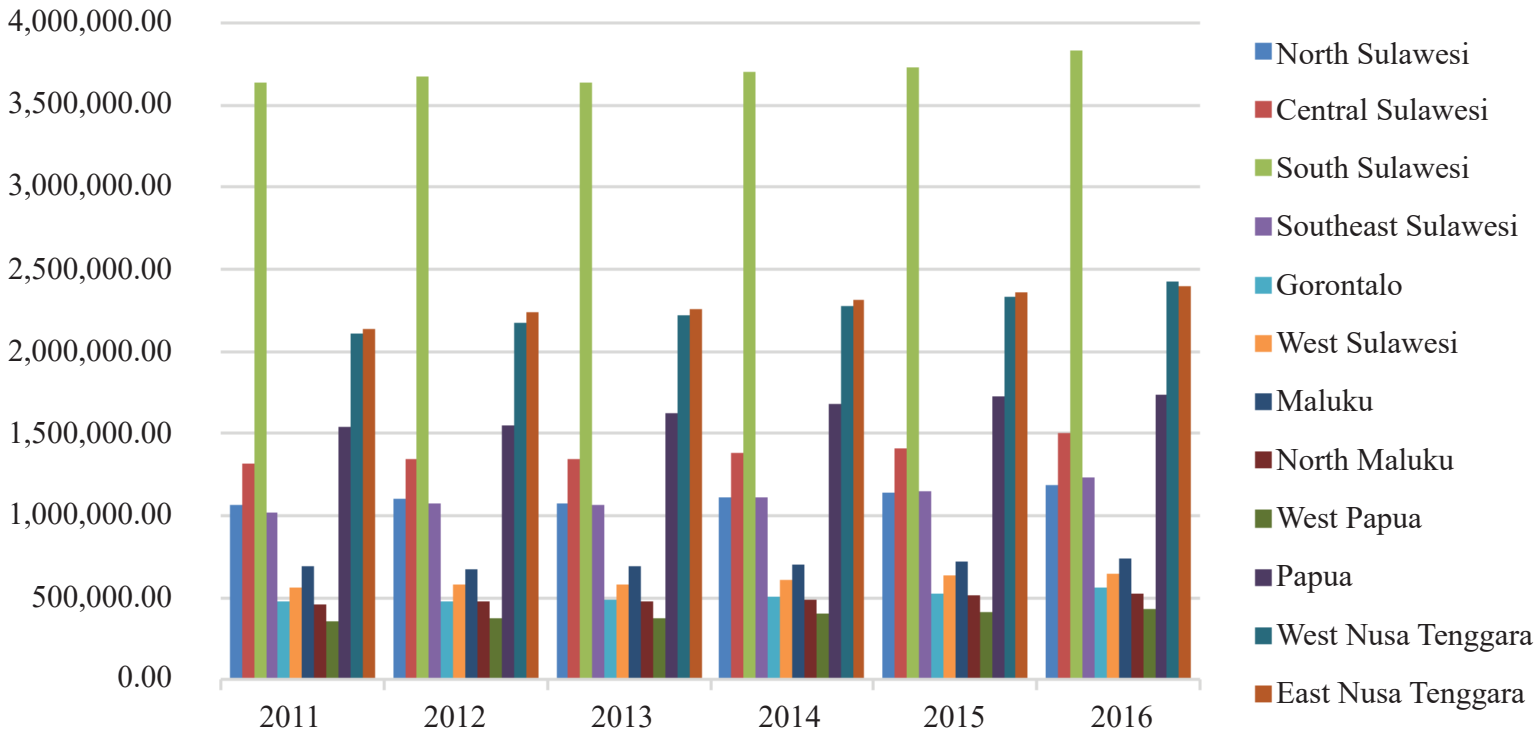

Source: The Central Bureau of Statistics, 2018

Figure 3. Labor in Eastern Indonesia Region 2011-2016 (people)

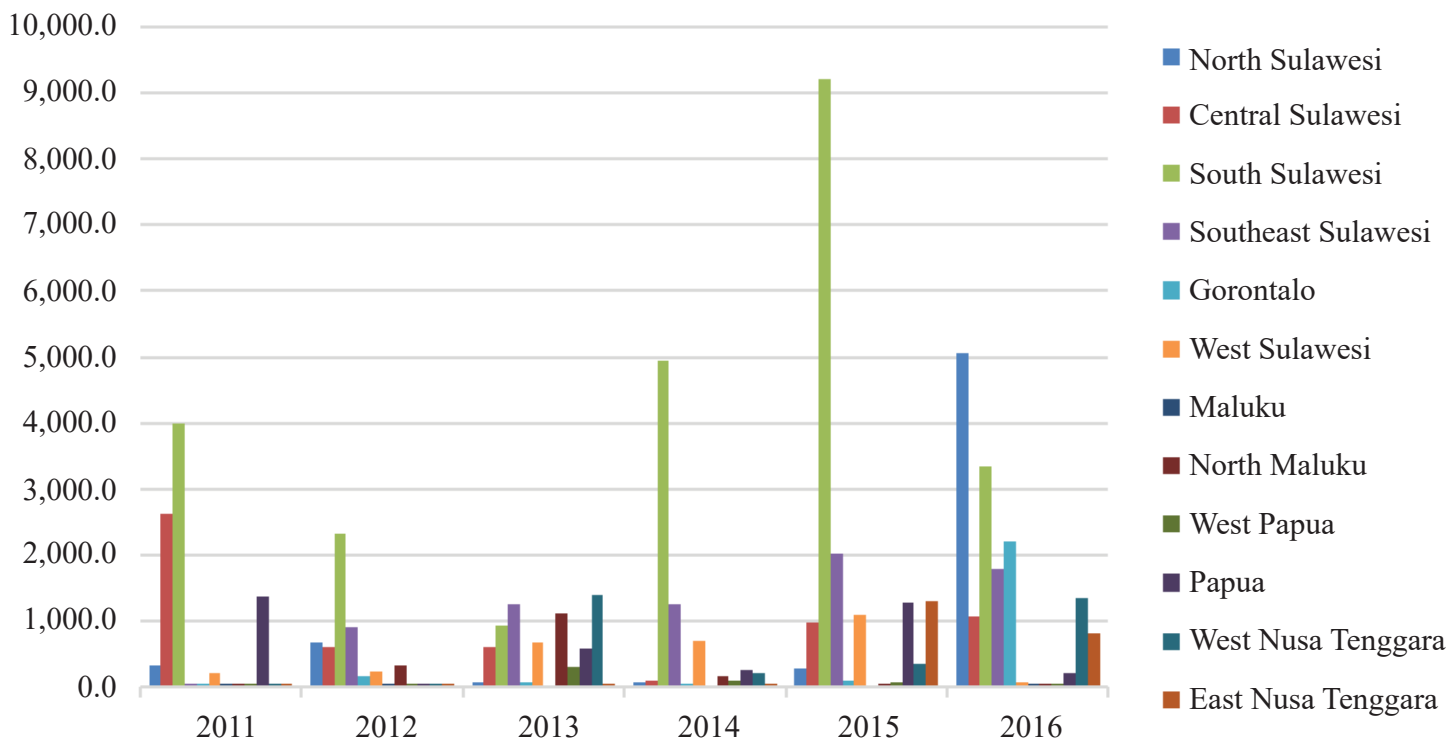

Source: The Central Bureau of Statistics, 2018

Figure 4. Domestic Investment in Eastern Indonesia Region 2011-2016 (Billion Rupiah) 


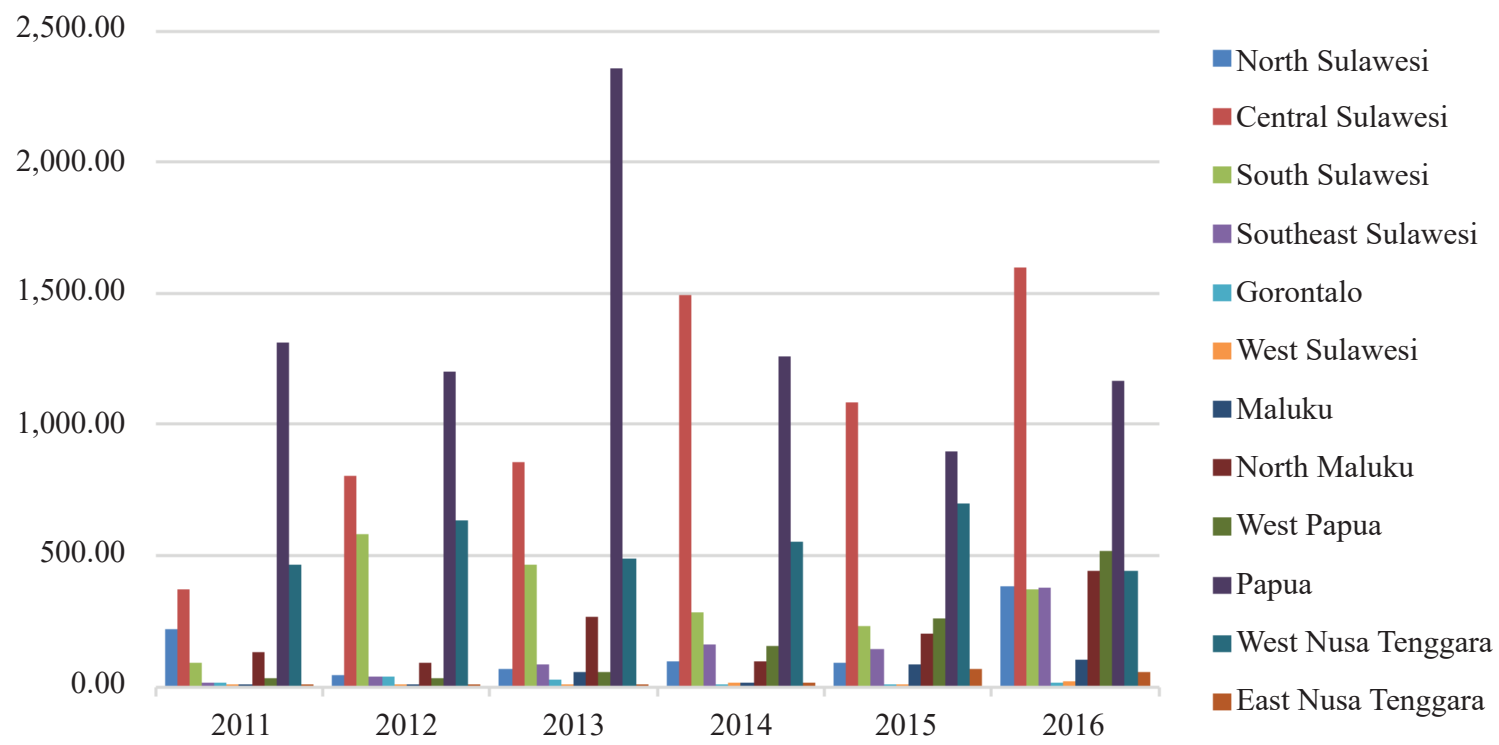

Source: The Central Bureau of Statistics, 2018

Figure 5. Foreign Direct Investment in Eastern Indonesia Region 2011-2016 (Million USD)

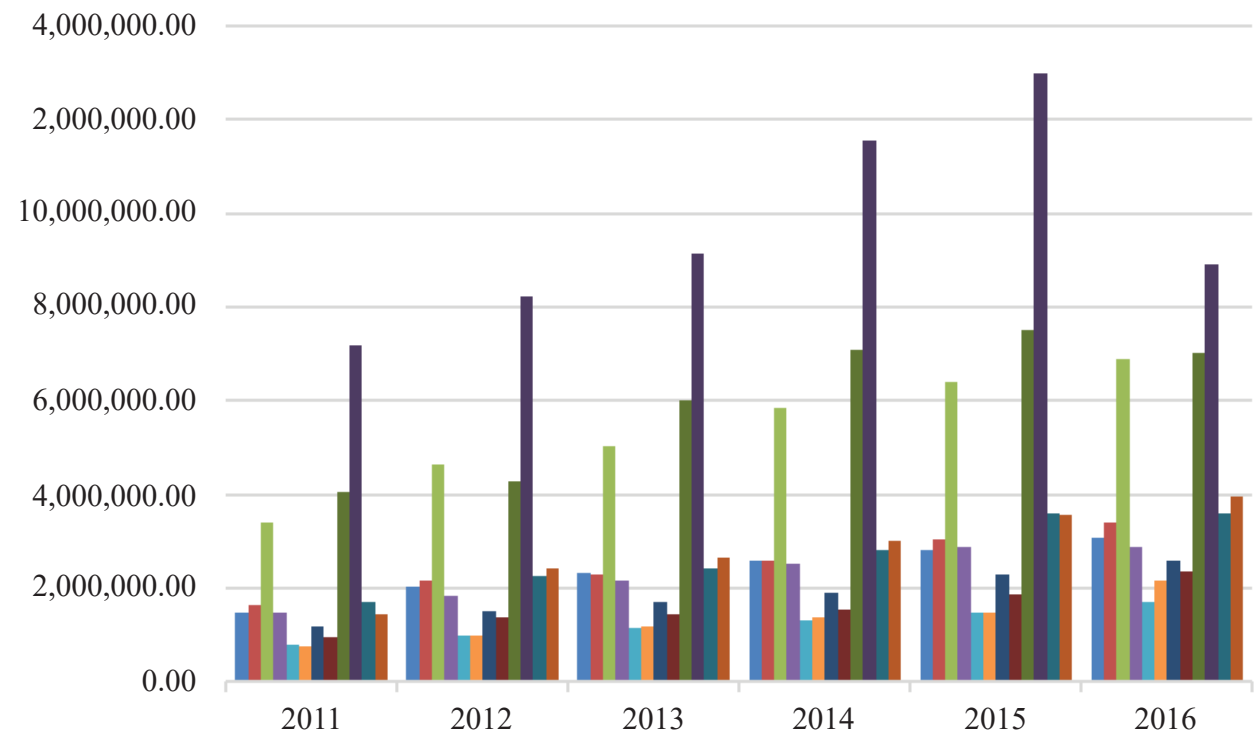

- North Sulawesi

-Central Sulawesi

- South Sulawesi

- Southeast Sulawesi

a Gorontalo

- West Sulawesi

-Maluku

- North Maluku

- West Papua

- Papua

- West Nusa Tenggara

- East Nusa Tenggara

Source: The Central Bureau of Statistics, 2018

Figure 6. Government Expenditure in Eastern Indonesia Region 2011-2016 (Billion Rupiah) 